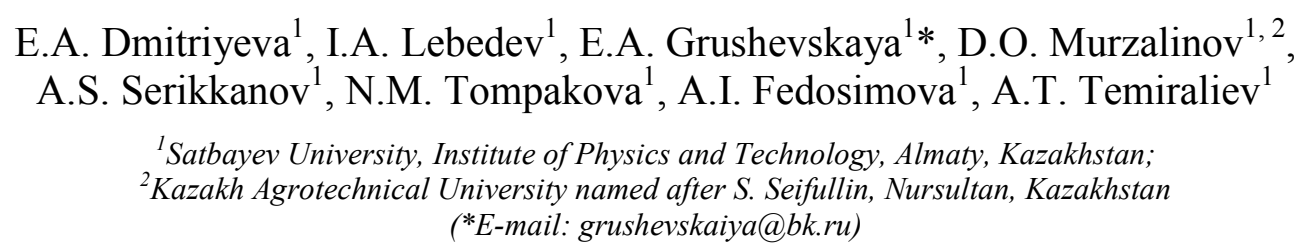

\title{
The effect of three-minute exposure of oxygen plasma on the properties of tin oxide films
}

\begin{abstract}
Research devoted to the effect of three-minute exposure of oxygen plasma on the properties of tin oxide films investigation. The films were obtained by sol-gel method from five-water tin tetrachloride solution. The concentration of tin ions in the $\mathrm{SnCl}_{4} / \mathrm{EtOH}$ film-forming system was $0.14 \mathrm{~mol} / \mathrm{l}$. The solution system was deposed on the glass substrate by carring out a modified dipping method. Plasma treatment was performed at a pressure of $6.5 \mathrm{~Pa}$ and a power of about 20 Watts. The frequency of the oscillations produced by the generator was $27.12 \pm 0.6 \% \mathrm{MHz}$ as well. The temperature of the samples during processing did not exceed $100{ }^{\circ} \mathrm{C}$. As a result of the formation of tin oxide (II), the film transmittance decreased after treatment with oxygen plasma. The width of the electric forbidden zone of the obtained samples was calculated, which was $3.95 \mathrm{eV}$ for glass and $3.79 \mathrm{eV}$ for film. The resistance of the films was determined by 10 measurements on different parts of the samples. The film without processing has a resistance of about $4255 \pm 1158 \mathrm{k} \Omega$, after processing, the resistance decreased by 25 times and amounted to $167 \pm 26 \mathrm{k} \Omega$. A decrease in resistance indicates an increase in the concentration of charge carriers in the sample. The resulting $\mathrm{SnO}$ is a semiconductor that lowers the transmittance of the studied films and contributes to reducing their resistance. X-ray structural analysis of the samples was also performed. After processing in oxygen plasma, the intensity of reflection from the (110) plane have increased. It should be noted that the number of planes with (101) indexes has decreased. The study of the sample surface showed the destructive nature of three-minute exposure by oxygen plasma.
\end{abstract}

Keywords: thin films, $\mathrm{SnO}_{2}$, sol-gel method, oxygen plasma treatment, transparency, structure, resistance, tin oxide (II).

\section{Introduction}

The study of tin oxide is associated with its multifunctional application. Tin dioxide belongs to a class of materials that combines high electrical conductivity with optical transparency and is therefore an important component for optoelectronic applications [1-3]. The lattice oxygen from the surface of the tin oxide is able to react chemically with the reagent and after the reaction to be renewed by the oxygen of the gas phase (mechanism of Mars - van Krevelen) [4]. This ability makes it possible to use $\mathrm{SnO}_{2}$ as a catalyst for oxidative processes [5-7]. The change in the resistance of tin oxide in the presence of various gases formed the basis for use as a sensitive element in gas sensors [8-10].

Among the various methods used to improve the functional properties of metal oxide layers, plasma treatment is of particular interest [11-13]. Analysis of changes in the optical parameters and structural characteristics of tin dioxide after plasma treatment allows us to better understand the dynamics of changes in the physical properties of thin films of tin dioxide.

\section{Experimental}

To produce $\mathrm{SnO}_{2}$ films, five-water tin tetrachloride was used as the initial reagent, and $97 \%$ ethanol was used as the solvent. In tin tetrachloride systems, ethanol does not precipitate longer than in water-based systems. $\mathrm{SnCl}_{4} / \mathrm{EtOH}$ film-forming systems with a tin ion concentration of $0.14 \mathrm{~mol} / 1$ were prepared. Filmforming systems were applied to substrates (glass slides) by a modified dipping method. They were air-dried for 1-2 minutes and annealed on IKA C-MAG HP7 electric stoves at a temperature of $400^{\circ} \mathrm{C}$ in the air. In this case, tin tetrachloride interacts with water from the air to form tin hydroxide and hydrochloric acid. Hydrochloric acid and solvent are removed from the film-forming system when heated, and unstable $\mathrm{Sn}(\mathrm{OH})_{4}$ decomposes to form water and the desired tin oxide by reaction $[14,15]$ :

$$
\mathrm{Sn}(\mathrm{OH})_{4} \rightarrow \mathrm{SnO}_{2}+2 \mathrm{H}_{2} \mathrm{O}
$$


12 layers were applied. The film thickness was determined by a microbalance [16] and amounted to $413=7 \mathrm{~nm}$.

Treatment of $\mathrm{SnO}_{2}$ thin films in oxygen plasma was performed in a quartz tube. Oxygen was obtained by pyrolytic decomposition of potassium permanganate:

$$
2 \mathrm{KMnO}_{4} \stackrel{\Delta}{\longrightarrow} \mathrm{K}_{2} \mathrm{MnO}_{4}+\mathrm{MnO}_{2}+\mathrm{O}_{2}
$$

Plasma treatment was performed at a pressure of $6.5 \mathrm{~Pa}$ and a power of about $20 \mathrm{Watts}$. The frequency of the oscillations produced by the generator was $27.12 \pm 0.6 \% \mathrm{MHz}$ as well. The temperature of the samples during processing did not exceed $100^{\circ} \mathrm{C}$. The processing time was 3 minutes.

Transmission and absorption spectra were measured using a UNICO SpectroQuest 2800 spectrophotometer. The structure of the films was studied using a scanning electron microscope JSM-6490LA, JEOL and an optical microscope MPE-11. To output data to a personal computer, a television camera for a vec-535 microscope was used. The composition of the films was determined using x-ray diffraction analysis on a DRON-6 diffractometer. The resistance of the films was determined using a UT70B multimeter. The distance between the contacts was $1 \mathrm{~mm}$.

\section{Results and Discussion}

\section{Optical property}

Figure 1 shows the transmission and absorption spectra of tin oxide thin films before and after oxygen plasma treatment.
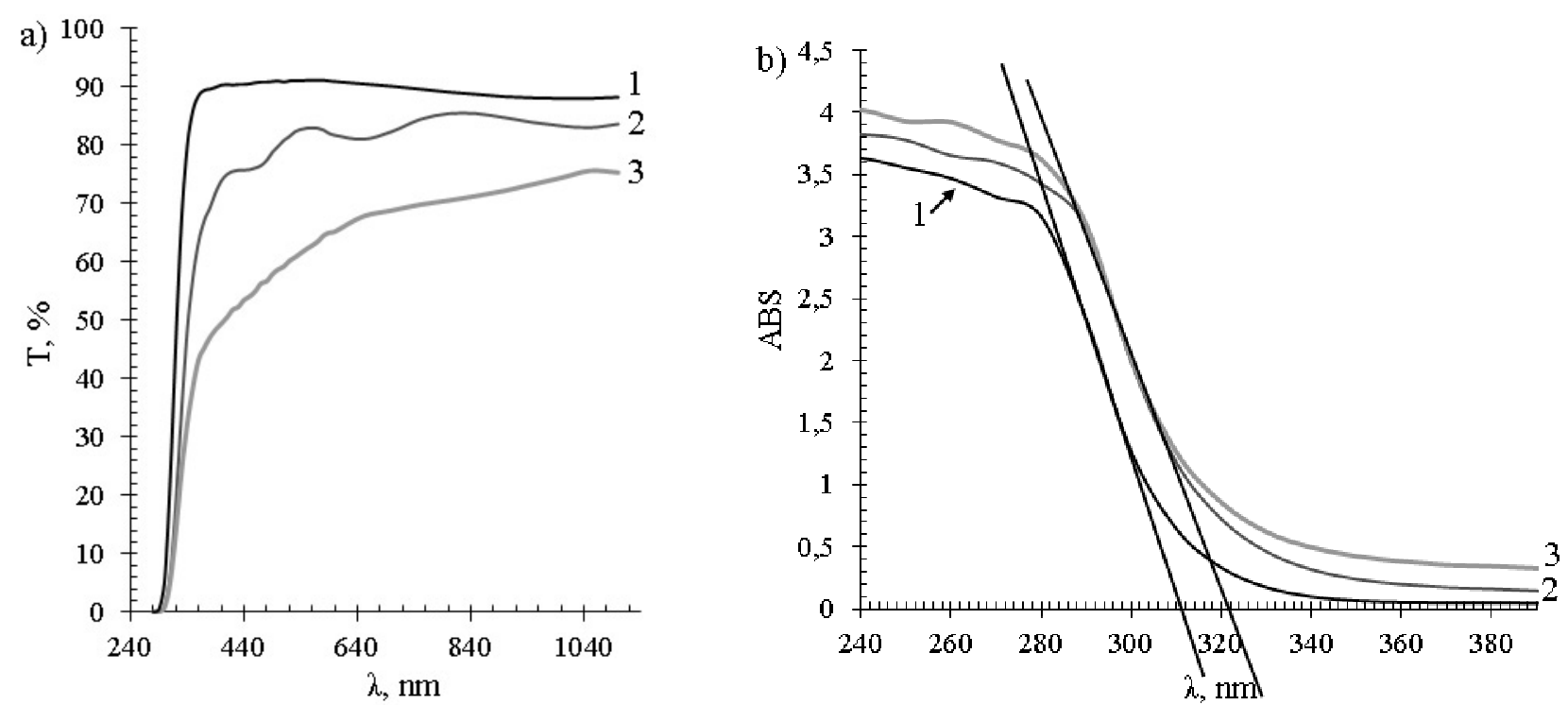

1 - glass substrate; 2 - film after application; 3 - film after plasma treatment

Figure 1. $a$ - transmission spectra of films; $b$ - absorption spectra of films

Figure $1 a$ shows that after treatment with oxygen plasma (Fig. 1a curve 3 ) the film transmittance has decreased compared to the film transmittance without processing (Fig. 1a nodding 2). The decrease in the transmission coefficient may be caused by the formation of compounds that are opaque in the visible region of the spectrum $[17,18]$. The formation of tin oxide (II) is most likely. The mechanism of formation of $\mathrm{SnO}$ in $\mathrm{SnO}_{2}$ films under the influence of oxygen-rich plasma in a chemically active (ionized) form requires further development. One of the assumptions, according to the» activated complex theory», is the formation of a complex of ionized oxygen with film defects. The resulting complex can decay to form $\mathrm{SnO}+\mathrm{O}_{2}$ or supplement the crystal structure to stoichiometric $\mathrm{SnO}_{2}$.

At the edge of the fundamental absorption (Fig. 1b) $\lambda_{\text {cr }}$ were determined for the glass substrate and film before and after treatment with oxygen plasma. For the glass substrate $\lambda_{\mathrm{cr}}=311 \mathrm{~nm}$, for the film without processing and after processing, the edge of the fundamental absorption coincided and $\lambda_{\mathrm{cr}}$ was $322 \mathrm{~nm}$. Using a well-known formula: 


$$
E g=(h c) / \lambda_{c r}
$$

where $h$ is the Planck constant in $\mathrm{eV}$; $c$ is the speed of light, and $\lambda_{c r}$ is the long-wave boundary of its own absorption. ed.

The width of the electric forbidden zone of the glass $-3.95 \mathrm{eV}$ and the film $-3.79 \mathrm{eV}$ were calculat-

\section{The resistance of the films}

The resistance of the films was determined by 10 measurements on different parts of the samples. Student's coefficient for 10 measurements is equal to 2.262 with a reliability of 0.95 . The error was calculated using the formula:

$$
\Delta \bar{A}=t_{\gamma, n-1} \frac{\sqrt{\frac{\sum_{i=1}^{n}\left(A_{i}-\bar{A}\right)^{2}}{n-1}}}{\sqrt{n}},
$$

where $\Delta \bar{A}-$ is the absolute measurement error; $t_{\gamma, n-1}$ - is the Student's coefficient; $A_{i}$ - is the value of the $i$-th measurement; $\bar{A}$ - is the arithmetic mean; $n-$ is the number of measurements.

Despite the fact that the width of the band gap of the film, calculated from the absorption spectra, did not change after processing, the resistance of the film significantly decreased. The film without processing has a resistance of $4255 \pm 1158 \mathrm{k} \Omega$, after processing, the resistance decreased by 25 times and amounted to $167 \pm 26 \mathrm{k} \Omega$.

The conductivity of tin dioxide is associated with the presence of intrinsic defects - oxygen vacancies that form small donor levels [19]. These levels can also be formed by impurities. A decrease in resistance indicates an increase in the concentration of charge carriers. The resulting $\mathrm{SnO}$, which reduces the transmittance, is a semiconductor and can also contribute to reducing the resistance.

\section{Diffraction analysis}

The source signal from thin films on a glass substrate has a high noise level. Using the method of increasing the signal-to-noise ratio [20,21], the following data were obtained and analyzed. Figure 2 shows the results of signal selection.
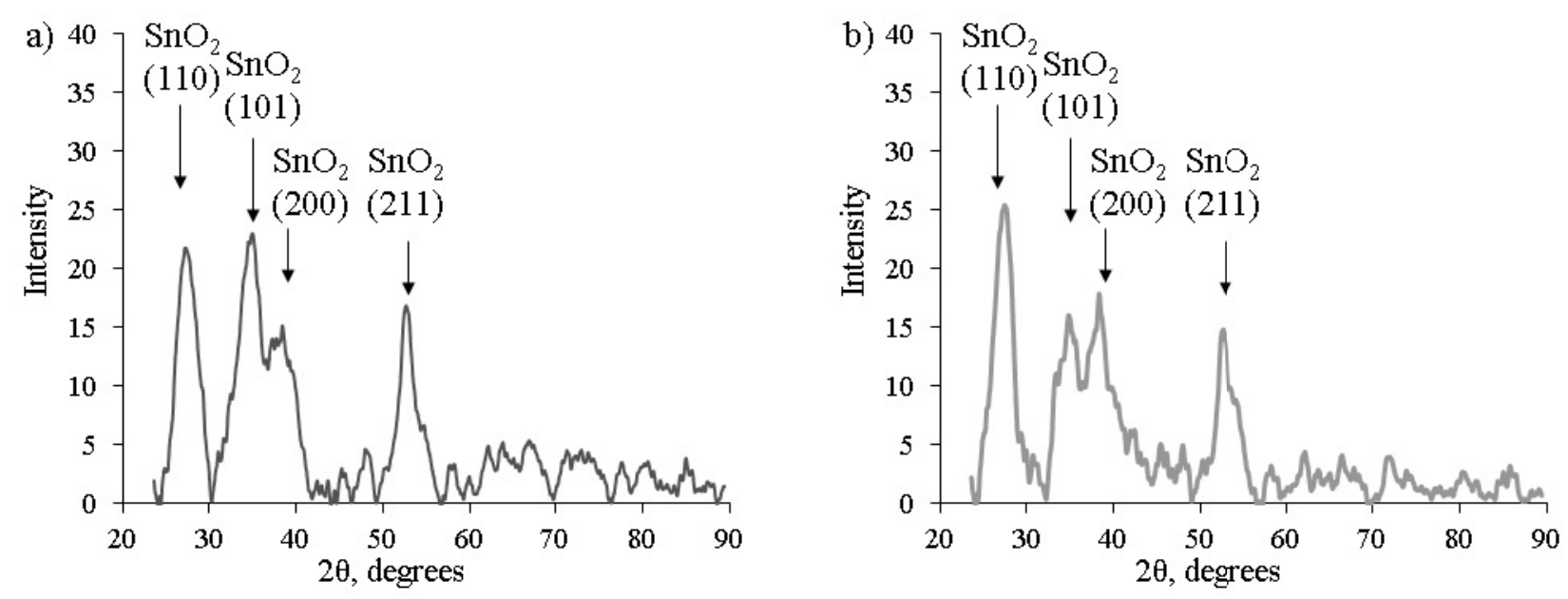

$$
a \text { - after application; } b \text { - after plasma treatment }
$$

Figure 2. X-ray diagram of tin oxide films

On X-ray diagrams (Fig. $2 a, b$ ) peaks of reflections from the $\mathrm{SnO}_{2}$ planes are observed. Peaks from other tin oxides are not observed. This indicates the absence of $\mathrm{SnO}$ in the crystalline form, and does not cancel the possibility of its existence in an amorphous state. It can be also noticed that the intensity of reflection from the (110) plane, after processing in oxygen plasma, increased. This indicates an increase in the number of planes with these Miller indexes. And the number of planes with indexes (101) has decreased. The destruction of crystallites along the planes (101) and (200) is associated with the transformation of the polycrystalline structure into a sub-nanometric cluster structure after plasma exposure [22, 23]. 
Surface structure

The surface structure depends on many parameters: the method of application, the concentration of the initial reagents, alloying impurities, etc. The dominant mechanism for the formation of spatial structures may be the phenomenon of self-organization [24]. Figure 3 shows images of the film surface after application and after plasma treatment.
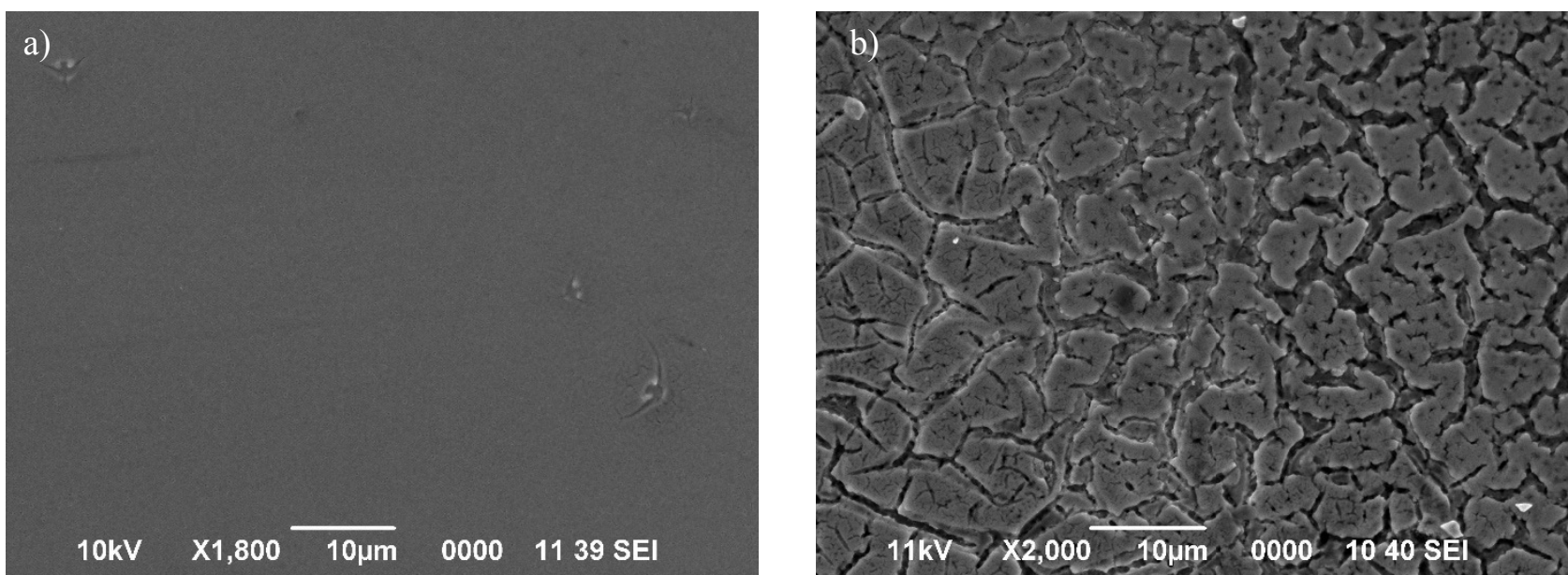

$a$ - after application; $b$ - after plasma treatment

Figure 3. SEM images of the surface of tin oxide films

Figure $3 a$ and $b$ show that three-minute oxygen plasma treatment is destructive. The surface of the film was cracked. Figure 4 shows photos of the surface taken with an optical microscope with a smaller magnification.
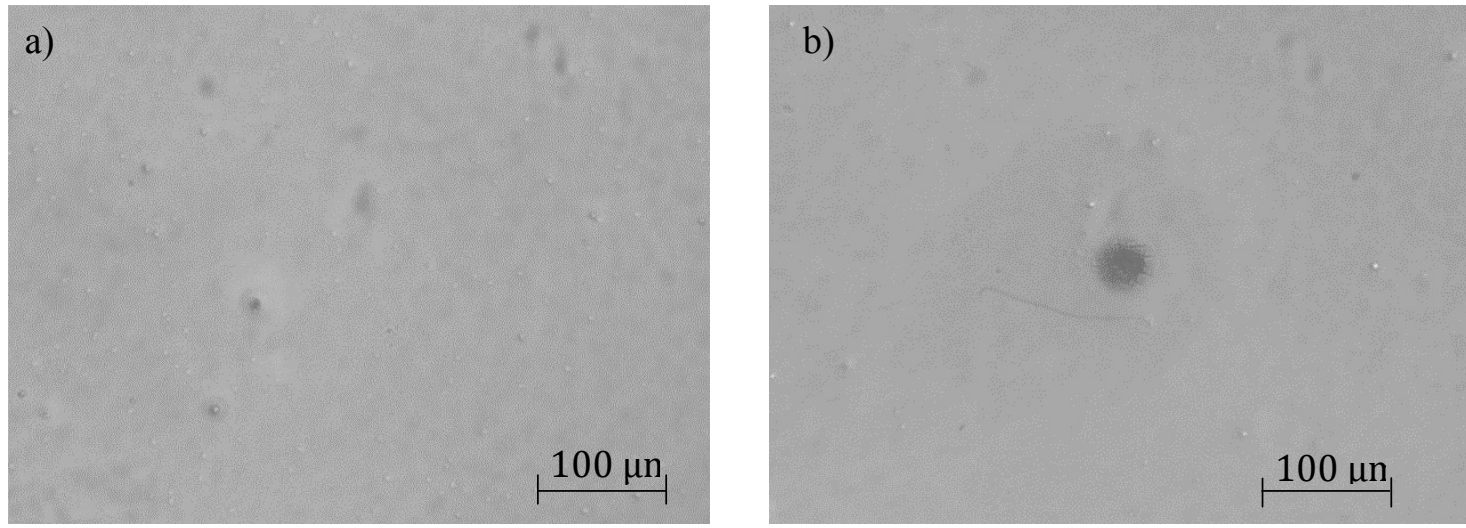

$a$ - after application; $b$ - after plasma treatment

Figure 4. Surface of tin oxide films obtained using an optical microscope

Figure $4 a$ shows that on the surface of the film after its application, there are rare, chaotically located hills - blisters [25]. They are formed by heating a wet gel. The reaction by-products and the solvent evaporate here. In places where the process of gelation has already begun, but evaporation has not yet occurred, the formation of blisters occurs. Figure $4 b$ shows that the highest and most exposed blisters have darkened. Probably, in these places that $\mathrm{SnO}$ is formed, and it reduces the transparency of the films.

\section{Conclusions}

It was found that treatment of a glow discharge with a low-temperature plasma in an oxygen-rich atmosphere for three minutes leads to a decrease in the transparency of the films. Also, as a result of this ef- 
fect, the resistance of the films is sharply reduced (by 25 times). There is a destructive effect of plasma in the destruction of $\mathrm{SnO}_{2}$ crystallites and the appearance of cracks at the micron level on the surface of the film. An increase in the conductivity of the films indicates the formation of additional charge sources. The formation of tin oxide (II) clusters in the places of large and opened blisters was revealed.

The work was carried out with the financial support of the Ministry of Education and Science on the topic BR05236404.

\section{References}

1 Cui H.T. Electrically conductive $\mathrm{TiO}_{2}$ /indium tin oxide coated glass substrates with high visible light transparency prepared by an electrodeposition method / H.T. Cui, Z.Q. Zheng // Thin solid films. - 2019. - Vol. 691. - P. 137612-137618. DOI: $10.1016 /$ j.tsf.2019.137612.

2 Mohammad T. Spray deposited indium doped tin oxide thin films for organic solar cell application / T. Mohammad, V. Kumar, V. Dutta // Physica e-low-dimensional systems \& nanostructures. — 2020. — Vol. 117. - P. 113793-113799. DOI: 10.1016/j.physe.2019.113793.

3 Ozen Y. $\mathrm{SnO}_{2}$ interlayer effects on the inverted polymer solar cells / Y. Ozen, I. Candan // Chemical physics letters. - 2020. — Vol. 740, Id. 137078. — P. 1-5. DOI: 10.1016/j.cplett.2019.137078.

4 Batzill M. The surface and materials science of tin oxide / M. Batzill, U. Diebold // Progress in Surface Science. — 2005. Vol. 79. - P. 47-154. DOI: 10.1016/j.progsurf.2005.09.002.

5 Zhang R.Y. Function promotion of $\mathrm{SO}_{4}{ }^{2-} / \mathrm{Al}_{2} \mathrm{O}_{3}-\mathrm{SnO}_{2}$ catalyst for biodiesel production from sewage sludge / R.Y. Zhang, F.F. Zhu, Y. Dong, X.M. Wu, Y.H. Sun, D.R. Zhang, T. Zhang, M.L. Han // Renewable energy. — 2020. - Vol. 147. - P. 275283. DOI: $10.1016 /$ j.renene.2019.08.141.

6 Chen Z. Wavy $\mathrm{SnO}_{2}$ catalyzed simultaneous reinforcement of carbon dioxide adsorption and activation towards electrochemical conversion of $\mathrm{CO}_{2}$ to $\mathrm{HCOOH} /$ Z. Chen, T.T. Fan, Y.Q. Zhang, J. Xiao, M.R. Gao, N.Q. Duan et al. // Applied catalysis b-environmental. — 2020. — Vol. 261. — P. 118243-118249. DOI: 10.1016/j.apcatb.2019.118243.

7 Zhang B.H. Well-dispersed $\mathrm{SnO}_{2}$ nanocrystals on N-doped carbon nanowires as efficient electrocatalysts for carbon dioxide reduction / B.H. Zhang, L.Z. Sun, Y.Q. Wang, S. Chen, J.T. Zhang // Journal of energy chemistry. — 2020. - Vol. 41. - P. 7-14. DOI: $10.1016 /$ j.jechem.2019.04.022.

8 Grushevskaya E.A. Sensitivity to ethanol vapour of thin films $\mathrm{SnO}_{2}$ doped with fluorine / E.A. Grushevskaya, S.A. Ibraimova, E.A. Dmitriyeva, I.A. Lebedev, K.A. Mit', D.M. Mukhamedshina, A.I. Fedosimova, A.S. Serikkanov, A.T. Temiraliev // Eurasian Chemico-Technological Journal. — 2019. — Vol. 21. — P. 13-17. DOI: 10.18321/ectj781.

9 Dmitriyeva E.A. Doping of fluorine of tin dioxide films synthesized by sol-gel method / E.A. Dmitriyeva, D.M. Mukhamedshina, K.A. Mit', I.A. Lebedev, I.I. Girina, A.I. Fedosimova, E.A. Grushevskaya // News of the National Academy of Sciences of the Republic of Kazakhstan (series of geology and technical sciences). - 2019. - Vol. 433. - P. 73-79. DOI: 10.32014/2019.2518-170X.9.

10 Manikandan V. A reliable chemiresistive sensor of nickel-doped tin oxide $\left(\mathrm{Ni}-\mathrm{SnO}_{2}\right)$ for sensing carbon dioxide gas and humidity / V. Manikandan, I. Petrila, S. Vigneselvan, R.S. Mane, B. Vasile, R. Dharmavarapu, S. Lundgaard, S. Juodkazis, J. Chandrasekaran // RSC advances. - 2020. - Vol. 10, Iss. 7. - P. 3796-3804. DOI: 10.1039/c9ra09579a.

11 Somjaijaroen N. Simultaneous O-2 plasma and thermal treatment for improved surface conductivity of Cu-Doped $\mathrm{SnO}_{2}$ films / N. Somjaijaroen, R. Sakdanuphab, N. Chanlek, P. Chirawatkul, A. Sakulkalavek // Vacuum. — 2019. — Vol. 166. - P. $212-217$. DOI: 10.1016/j.vacuum.2019.05.017.

12 Stuckert E.P. Ar/O-2 and $\mathrm{H}_{2} \mathrm{O}$ plasma surface modification of $\mathrm{SnO}_{2}$ nanomaterials to increase surface oxidation / E.P. Stuckert, E.R. Fisher // Sensors and actuators b-chemical. -2015 . - Vol. 208. — P. 379-388. DOI: 10.1016/j.snb.2014.11.049.

13 Seo H.B. Effects of plasma treatment on the composition and phase changes of sputter-deposited $\mathrm{SnO}_{\mathrm{x}}$ thin films / H.B. Seo, B.S. Bae, H.I. Bang, E.J. Yun // Journal of nanoscience and nanotechnology. - 2020. — Vol. 20, Iss. 1. — P. 197-205. DOI: $10.1166 /$ jnn.2020.17225.

14 Neeraj K. Mishra. Structural and optical properties of $\mathrm{SnO}_{2}-\mathrm{Al}_{2} \mathrm{O}_{3}$ nanocomposite synthesized via sol-gel route / Neeraj K. Mishra, Chaitnaya Kumar, Amit Kumar, Manish Kumar, Pratibha Chaudhary, Rajeev Singh // Materials Science-Poland. — 2015. — Vol. 33, No. 4. - P. 714-718. DOI: 10.1515/msp-2015-0101.

15 Ярмонов А.Н. Получение оптически прозрачных токопроводящих покрытий термическим испарением / А.Н. Ярмонов, Д.Д. Ларионов, Р.Р. Яхиханов // Изв. Самар. науч. центра РАН. — 2015. — Т. 17, № 2(4). — С. $936-939$.

16 Dmitrieva E.A. The effect of $\mathrm{NH}_{4} \mathrm{~F}$ and $\mathrm{NH}_{4} \mathrm{OH}$ on the structure and physical properties of thin $\mathrm{SnO}_{2}$ films synthesized by the sol-gel method / E.A. Dmitrieva, D.M. Mukhamedshina, N.B. Beisenkhanov, K.A. Mit' // Glass Physics and Chemistry. - 2014. — Vol. 40, No. 1. - P. 31-36. DOI:10.1134/S1087659614010076.

17 Mukhamedshina D.M. Influence of plasma treatment on physical properties of thin $\mathrm{SnO}_{2}$ films obtained from $\mathrm{SnCl}_{4}$ solutions with additions of $\mathrm{NH}_{4} \mathrm{~F}$ and $\mathrm{NH}_{4} \mathrm{OH} /$ D.M. Mukhamedshina, A.I. Fedosimova, E.A. Dmitriyeva, I.A. Lebedev, E.A. Grushevskaya, S.A. Ibraimova, K.A. Mit', A.S. Serikkanov // Eurasian Chemico-Technological Journal. — 2019. — Vol. 21. — P. 57-61.

18 Томпакова Н.М. Влияние трехминутной обработки водородной плазмой на структуру и свойства тонких пленок $\mathrm{SnO}_{2}$ / Н.М. Томпакова, Е.А. Дмитриева, Е.А. Грушевская, И.А. Лебедев, А.С. Серикканов, Д.М. Мухамедшина, К.А. Мить // Recent Contributions to Physics. — 2019. — № 4(71). - C. 67-74. https://doi.org/10.26577/RCPh-2019-i4-9.

19 Kiliç C. Origins of coexistence of conductivity and transparency in $\mathrm{SnO}_{2}$ / C. Kiliç, A. Zunger // Physical Review Letters. 2002. - Vol. 88. - P. 1-4. 
20 Грушевская Е.А. Способ увеличения отношения сигнал/шум в ЭПР спектроскопии / Е.А. Грушевская, Е.А. Дмитриева, И.А. Лебедев, Ю.А. Рябикин, А.Т. Темиралиев, А.И. Федосимова // Вестн. Казах. нац. ун-та. Сер. Физика. — 2018. № 2(65). - С. 76-82.

21 Предварительный патент 12779. Казахстан. Способ увеличения отношения сигнал/шум в спектроскопии / Ю.А. Рябикин, И.А. Лебедев. — МПК G01N 24/00. 2001.

22 Mukhamedshina D.M. Influence of plasma treatments on the properties of $\mathrm{SnO}_{\mathrm{x}}$ thin films / D.M. Mukhamedshina, N.B. Beisenkhanov, K.A. Mit', V.A. Botvin, I.V. Valitova, E.A. Dmitrieva // High Temperature Material Processes. — 2006. - Vol. 10. - P. 603-615. DOI: 10.1615/HighTempMatProc.v10.i4.110.

23 Mukhamedshina D.M. Influence of plasma treatments on the microstructure and electrophysical properties of $\mathrm{SnO}_{\mathrm{x}}$ thin films synthesized by magnetron sputtering and sol-gel technique / D.M. Mukhamedshina, K.A. Mit', N.B. Beisenkhanov, E.A. Dmitriyeva, I.V. Valitova // Journal of Materials Science-Materials in Electronics. — 2008. — Vol. 19. — P. 382-387. DOI: 10.1007/s10854008-9695-0.

24 Fedosimova A.I. Modeling the process of formation of fractal structures in thin films / A.I. Fedosimova, E.A. Dmitrieva, I.A. Lebedev, A.T. Temiraliev, M.E. Abishev, B.A. Baitimbetova, Yu.A. Ryabikin, A.S. Serikkanov // IOP Conf. Series: Journal of Physics: Conf. Series. — 2018. — Vol. 1141, Id. 012004. — P. 1-7. DOI: 10.1088/1742-6596/1141/1/012004.

25 Guo T. High temperature brittle film adhesion measured from annealing-induced circular blisters / T. Guo, J.Y. He, X.L. Pang, A.A. Volinsky, Y.J. Su, L.J. Qiao // Acta materialia. - 2017. — Vol. 138. - P.1-9. DOI: 10.1016/j.actamat.2017.07.026.

Е.А. Дмитриева, И.А. Лебедев, Е.А. Грушевская, Д.О. Мурзалинов, А.С. Серикканов, Н.М. Томпакова, А.И. Федосимова, А.Т. Темиралиев

\title{
Оттегі плазмасының үш минуттық қалайы оксиді қабықшаларының қасиеттеріне әсері
}

\begin{abstract}
Оттегі плазмасының үш минуттық қалайы оксиді қабықшаларының қасиеттеріне әсері зерттелген. Қабықшалар бес текті тетрахлорид қалайының ерітіндісінен золь-гель әдісімен алынған. $\mathrm{SnCl}_{4} / \mathrm{EtOH}$ қабықша түзуші жүйесіндегі қалайы иондарының концентрациясы 0,14 моль/л құрайды. Шыныдан жасалған төсенішке ерітінді батыру әдісімен жағылды. Плазма өңдеуі қысымы 6,5 Па және куаттылығы 20 Ватт шамасында жүргізілген. Генератор жасайтын тербеліс жиілігі 27,12 \pm 0,6 \%-МГцді құрады. Өңдеу кезіндегі үлгілердің температурасы $100^{\circ} \mathrm{C}$-тан артылмады. Оттегі плазмасымен өңдеуден кейін (II) валентті қалайы оксидінің пайда болуы салдарынан қабықшаның өткізу коэффициенті төмендеді. Алынған үлгілердің электрондық шекті зонасының аймағы есептелген, ол шыны төсеніш үшін — 3,95 эВ, қабықша үшін - 3,79 эВ. Қабықшалардың кедергісі үлгілердің 10 әртүрлі нүктелік аймағында өлшеніп, анықталған. Өңдеусіз қабықшаның кедергісі $4255 \pm 1158$ кОм-ға тең болады, өңдеуден кейін олардың кедергісі 25 есе азайды және шамасы $167 \pm 26$ кОм құрады. Кедергінің кемуі заряд тасымалдаушылардың концентрациясының ұлғаюын көрсеткен. Зерттеу барысында пайда болған $\mathrm{SnO}$ қабықшалардың өткізу коэффициентін төмендететін және олардың кедергісін азайтуға үлес қосатын жартылай өткізгіш болып табылады. Үлгілерге рентген талдауы да жүргізілген. Оттегі плазмасында өңдеуден кейін (110) жазықтықтан шағылысу интенсивтілігі артты. Бұл жерде (101) индексі бар жазықтар саны азайғанын да атап өту керек. Үлгілердің беттік зерттеуі оттегі плазмасының үш минуттық әсерінің деструктивті сипатын көрсеткен.
\end{abstract}

Кілm сөздер: жұқа қабықшалар, $\mathrm{SnO}_{2}$, золь-гель әдісі, оттегі плазмасымен өңдеу, мөлдірлілік, қабықша құрылымы, кедергі, (II) валентті қалайы оксиді.

\section{Е.А. Дмитриева, И.А. Лебедев, Е.А. Грушевская, Д.О. Мурзалинов,} А.С. Серикканов, Н.М. Томпакова, А.И. Федосимова, А.Т. Темиралиев

\section{Влияние трехминутного воздействия кислородной плазмой на свойства пленок оксида олова}

\begin{abstract}
Исследовано влияние трехминутного воздействия кислородной плазмой на свойства пленок оксида олова. Пленки были получены золь-гель методом из пятиводного тетрахлорида олова. Концентрация ионов олова в пленкообразующей системе $\mathrm{SnCl}_{4} / \mathrm{EtOH}$ составляла 0,14 моль/л. Нанесение на стеклянную подложку проводилось модифицированным методом окунания. Обработка плазмой осуществлялась при давлении 6,5 Па и мощности около 20 Вт. Частота колебаний, создаваемых генератором, составляла 27,12 МГц $\pm 0,6 \%$. Температура образцов при обработке не превышала $100{ }^{\circ} \mathrm{C}$. Вследствие образования оксида олова (II) понизился коэффициент пропускания пленки после обработки кислородной плазмой. Рассчитана ширина запрещенной зоны полученных образцов, которая для стекла составила 3,95 эВ, для пленки - 3,79 эВ. Сопротивление пленок определялось по 10 измерениям на разных участках образцов. Пленка без обработки обладает сопротивлением $4255 \pm 1158$ кОм, после
\end{abstract}


обработки сопротивление уменьшилось в 25 раз и составило $167 \pm 26$ кОм. Уменьшение сопротивления указывает на увеличение концентрации носителей заряда. Образовавшийся $\mathrm{SnO}$ является полупроводником, который понижает коэффициент пропускания исследуемых пленок и вносит вклад в уменьшение их сопротивления. Проведен рентгеноструктурный анализ образцов. После обработки в кислородной плазме повысилась интенсивность отражения от плоскости (110). Следует отметить, что количество плоскостей с индексами (101) уменьшилось. Исследование поверхности образцов показало деструктивный характер трехминутного воздействия кислородной плазмой.

Ключевые слова: тонкие пленки, $\mathrm{SnO}_{2}$, золь-гель метод, обработка кислородной плазмой, прозрачность, структура, сопротивление, оксид олова (II).

\section{References}

1 Cui, H.T., \& Zheng, Z.Q. (2019). Electrically conductive $\mathrm{TiO}_{2}$ /indium tin oxide coated glass substrates with high visible light transparency prepared by an electrodeposition method. Thin solid films, 691, 137612-137618. DOI: 10.1016/j.tsf.2019.137612.

2 Mohammad, T., Kumar, V., \& Dutta, V. (2020). Spray deposited indium doped tin oxide thin films for organic solar cell application. Physica e-low-dimensional systems \& nanostructures, 117, 113793-113799. DOI: 10.1016/j.physe.2019.113793.

3 Ozen, Y., \& Candan, I. (2020). $\mathrm{SnO}_{2}$ interlayer effects on the inverted polymer solar cells. Chemical physics letters, 740, 137078, 1-5. DOI: 10.1016/j.cplett.2019.137078.

4 Batzill, M., \& Diebold, U. (2005). The surface and materials science of tin oxide. Progress in Surface Science, 79, 47-154. DOI: 10.1016/j.progsurf.2005.09.002.

5 Zhang, R.Y., Zhu, F.F., Dong, Y., Wu, X.M., Sun, Y.H., Zhang, D.R., Zhang, T., \& Han, M.L. (2020). Function promotion of $\mathrm{SO}_{4}^{2-} / \mathrm{Al}_{2} \mathrm{O}_{3}-\mathrm{SnO}_{2}$ catalyst for biodiesel production from sewage sludge. Renewable energy, 147, 275-283. DOI: 10.1016/j.renene.2019.08.141.

6 Chen, Z., Fan, T.T., Zhang, Y.Q., Xiao, J., Gao, M.R., \& Duan, N.Q., et al. (2020). Wavy $\mathrm{SnO}_{2}$ catalyzed simultaneous reinforcement of carbon dioxide adsorption and activation towards electrochemical conversion of $\mathrm{CO}_{2}$ to HCOOH. Applied catalysis b-environmental, 261, UNSP 118243-118249. DOI: 10.1016/j.apcatb.2019.118243.

7 Zhang, B.H., Sun, L.Z., Wang, Y.Q., Chen, S., \& Zhang, J.T. (2020). Well-dispersed $\mathrm{SnO}_{2}$ nanocrystals on N-doped carbon nanowires as efficient electrocatalysts for carbon dioxide reduction. Journal of energy chemistry, 41, 7-14. DOI: 10.1016/j.jechem.2019.04.022.

8 Grushevskaya, E.A., Ibraimova, S.A., Dmitriyeva, E.A., Lebedev, I.A., Mit', K.A., Mukhamedshina, D.M., \& Fedosimova, A.I., et al. (2019). Sensitivity to ethanol vapour of thin films $\mathrm{SnO}_{2}$ doped with fluorine. Eurasian ChemicoTechnological Journal, 21, 13-17. DOI: 10.18321/ectj781.

9 Dmitriyeva, E.A., Mukhamedshina, D.M., Mit', K.A., Lebedev, I.A., Girina, I.I., Fedosimova, A.I., \& Grushevskaya, E.A. (2019). Doping of fluorine of tin dioxide films synthesized by sol-gel method. News of the National Academy of Sciences of the Republic of Kazakhstan (series of geology and technical sciences), 433, 73-79. DOI: 10.32014/2019.2518-170X.9.

10 Manikandan, V., Petrila, I., Vigneselvan, S., Mane, R.S., Vasile, B., Dharmavarapu, R., \& Lundgaard, S., et al. (2020). A reliable chemiresistive sensor of nickel-doped tin oxide $\left(\mathrm{Ni}-\mathrm{SnO}_{2}\right)$ for sensing carbon dioxide gas and humidity. RSC advances, 10(7), 3796-3804. DOI: 10.1039/c9ra09579a.

11 Somjaijaroen, N., Sakdanuphab, R., Chanlek, N., Chirawatkul, P., \& Sakulkalavek, A. (2019). Simultaneous O-2 plasma and thermal treatment for improved surface conductivity of $\mathrm{Cu}$-Doped $\mathrm{SnO}_{2}$ films. Vacuum, 166, $212-217 . \quad \mathrm{DOI}$ : 10.1016/j.vacuum.2019.05.017.

12 Stuckert, E.P., \& Fisher, E.R. (2015). Ar/O-2 and $\mathrm{H}_{2} \mathrm{O}$ plasma surface modification of $\mathrm{SnO}_{2}$ nanomaterials to increase surface oxidation. Sensors and actuators b-chemical, 208, 379-388. DOI: 10.1016/j.snb.2014.11.049.

13 Seo, H.B., Bae, B.S., Bang, H.I., \& Yun, E.J. (2020). Effects of plasma treatment on the composition and phase changes of sputter-deposited $\mathrm{SnO}_{\mathrm{x}}$ thin films. Journal of nanoscience and nanotechnology, 20(1), 197-205. DOI: 10.1166/jnn.2020.17225.

14 Neeraj K. Mishra, Chaitnaya Kumar, Amit Kumar, Manish Kumar, Pratibha Chaudhary \& Rajeev Singh. (2015). Structural and optical properties of $\mathrm{SnO}_{2}-\mathrm{Al}_{2} \mathrm{O}_{3}$ nanocomposite synthesized via sol-gel route. Materials Science-Poland, 33(4), 714-718. DOI: $10.1515 / \mathrm{msp}-2015-0101$.

15 Yarmonov, A.N., Larionov, D.D., \& Yakhikhanov, R.R. (2015). Poluchenie opticheski prozrachnykh tokoprovodiashchikh pokrytii termicheskim ispareniem [Obtaining optically transparent conductive coatings by thermal evaporation]. Izvestiia Samarskoho nauchnoho tsentra Rossiiskoi akademii nauk - Proceedings of the Samara scientific center of the Russian Academy of Sciences, 17, 2(4), 936-939 [in Russian].

16 Dmitrieva, E.A., Mukhamedshina, D.M., Beisenkhanov, N.B., \& Mit', K.A. (2014). The effect of $\mathrm{NH}_{4} \mathrm{~F}$ and $\mathrm{NH}_{4} \mathrm{OH}$ on the structure and physical properties of thin $\mathrm{SnO}_{2}$ films synthesized by the sol-gel method. Glass Physics and Chemistry, 40(1), 31-36. DOI: $10.1134 /$ S1087659614010076.

17 Mukhamedshina, D.M., Fedosimova, A.I., Dmitriyeva, E.A., Lebedev, I.A., Grushevskaya, E.A., Ibraimova, S.A., \& Mit', K.A., et al. (2019). Influence of plasma treatment on physical properties of thin $\mathrm{SnO}_{2}$ films obtained from $\mathrm{SnCl}_{4}$ solutions with additions of $\mathrm{NH}_{4} \mathrm{~F}$ and $\mathrm{NH}_{4} \mathrm{OH}$. Eurasian Chemico-Technological Journal, 21, 57-61.

18 Tompakova, N.M., Dmitriyeva, E.A., Grushevskaya, E.A., Lebedev, I.A., Serikkanov, A.S., Mukhamedshina, D.M., \& Mit, K.A. (2019). Vliianie trekhminutnoi obrabotki vodorodnoi plazmoi na strukturu i svoistva tonkikh plenok $\mathrm{SnO}_{2}$ [The effect of a three-minute treatment with hydrogen plasma on the structure and properties of thin $\mathrm{SnO}_{2}$ films]. Recent Contributions to Physics, 4(71), 67-74. https://doi.org/10.26577/RCPh-2019-i4-9 [in Russian]. $1-4$.

19 Kiliç, C., \& Zunger, A. (2002). Origins of coexistence of conductivity and transparency in $\mathrm{SnO}_{2}$. Physical Review Letters, 88, 
20 Grushevskaya, E.A., Dmitriyeva, E.A., Lebedev, I.A., Ryabikin, Yu.A., Temiraliyev, A.T. \& Fedosimova, A.I. (2018). Sposob uvelicheniia otnosheniia sihnal/shum v EPR spektroskopii [The way to increase the signal-to-noise ratio in EPR spectroscopy]. Vestnik Kazakhskoho natsionalnoho universiteta. Seriia Fizika - Bulletin of Kazakh National University. Physics series, 2(65), $76-82$ [in Russian].

21 Riabikin, Yu.A., \& Lebedev, I.A. (2001). Sposob uvelicheniia otnosheniia sihnal/shum v spektroskopii [Method for increasing signal-to-noise ratio in spectroscopy]. Preliminary patent No. 12779. MPK G01N 24/00. Kazakhstan [in Russian].

22 Mukhamedshina, D.M., Beisenkhanov, N.B., Mit', K.A., Botvin, V.A., Valitova, I.V., \& Dmitrieva, E.A. (2006). Influence of plasma treatments on the properties of $\mathrm{SnO}_{\mathrm{x}}$ thin films. High Temperature Material Processes, 10, 603-615. DOI: 10.1615/HighTempMatProc.v10.i4.110.

23 Mukhamedshina, D.M., Mit', K.A., Beisenkhanov, N.B., Dmitriyeva, E.A., \& Valitova I.V. (2008). Influence of plasma treatments on the microstructure and electrophysical properties of $\mathrm{SnO}_{\mathrm{x}}$ thin films synthesized by magnetron sputtering and sol-gel technique. Journal of Materials Science-Materials in Electronics, 19, 382-387. DOI: 10.1007/s10854-008-9695-0.

24 Fedosimova, A.I., Dmitrieva, E.A., Lebedev, I.A., Temiraliev, A.T., Temiraliev, A.T., Abishev, M.E., \& Baitimbetova, B.A., et al. (2018). Modeling the process of formation of fractal structures in thin films. IOP Conf. Series: Journal of Physics: Conf. Series, 1141, 012004, 1-7. DOI: 10.1088/1742-6596/1141/1/012004.

25 Guo, T., He, J.Y., Pang, X.L., Volinsky, A.A., Su, Y.J., \& Qiao, L.J. (2017). High temperature brittle film adhesion measured from annealing-induced circular blisters. Acta materialia, 138, 1-9. DOI: 10.1016/j.actamat.2017.07.026. 